\title{
Conflict, democracy and voter choice: a public choice analysis of the Athenian ostracism
}

\author{
George Tridimas ${ }^{1}$
}

Received: 18 April 2016/Accepted: 24 September 2016/Published online: 1 October 2016

(C) The Author(s) 2016. This article is published with open access at Springerlink.com

\begin{abstract}
Ostracism, the removal of a political leader from ancient Athens for a period of ten years without any additional financial sanction or other punishment, was an important and rather unique institutional aspect of the direct democracy. The present study explains the adoption of ostracism as the utility maximizing choice of a self-interested constitutional writer-cum-political actor to resolve violent political conflict and illustrates that it acted as a type of negative referendum on politicians. Using notions from game theory and spatial decision modeling, the paper goes on to attribute the infrequent use of ostracism to its two-stage decision making process wherein the decisive voter of the first stage differed from the decisive voter of the second stage.
\end{abstract}

Keywords Ancient Athens · Ostracism · Intra-elite conflict · Constitutional choice · Backward induction

JEL Classification D7: Analysis of Collective Decision making - D72: Political Processes · D74: Conflict Conflict Resolution Alliances · N4: Economic HistoryGovernment · N93-Europe: Pre-1913 Regional and Urban History

The original ancient Greek texts referred to in this work can be found along with English translations on the website of the Perseus Project http://www.perseus.tufts.edu.

George Tridimas

G.Tridimas@ulster.ac.uk

1 Department of Accounting Finance and Economics, Ulster Business School, Shore Road,

Newtownabbey BT37 0QB, UK 


\section{Introduction}

The fundamental kinship of ancient and modern democracy has led modern researchers to apply the methodology of public choice to gain a better understanding of the practices of the ancient Greek democracies. ${ }^{1}$ The present study follows this approach and offers new rational theory perspectives on ostracism, a distinct characteristic of the direct democracy of ancient Athens, 508-322 (all dates BCE), by which the demos in a two-stage ballot decided to banish a political leader for a period of ten years. From a modern perspective ostracism may sound as a bizarre practice and a harsh punishment that violates individual rights. According to the Athenian Constitution of Aristotle (22.1-4), ostracism was enacted as a precaution against men in powerful positions to defend the demos from potential tyrants. Even though the ancient biographer Plutarch considered it as motivated by envy against prominent citizens (see, for example, Plutarch, Parallel Lives, Aristides, 7.2), it put a stop to earlier violent political contests, after which the winning side typically exiled the losing side and confiscated its property. Ostracism was a potent weapon to eliminate leading individuals, at least temporarily, but it was deployed sparingly, used ten times in the period 507-416 with no ostracisms taking place after that date, although the procedure was not removed from the statutes.

Ancient history scholarship has highlighted that ostracism accomplished several things: not only could it defend democracy, but it also provided a powerful mechanism for resolving intra-elite conflicts peacefully, while simultaneously ascertaining the supremacy of the demos over elites; it also broke policy impasses. It was an important fixture of the institutional landscape of ancient Athens. Yet, contrary to other elements of the Athenian democracy, there is no formal analysis of its characteristics in the contemporary collective choice literature. The present paper aims to fill this gap by looking at the use of ostracism through the lens of rational choice theory, thereby adding to political economy research on historical societies ${ }^{2}$ and to the rational choice literature on non-traditional legal institutions (see, for example, Becker and Stigler 1974; Leeson 2007; Leeson and Coyne 2012). It focuses on two issues. First, considering Cleisthenes, the constitutional writer of the law of ostracism as a rational self-interested actor, the paper inquires into why he introduced ostracism as a method of resolving contests for political power among rival elites, instead of continuing the previous norm of violent conflict and mass exile. Second, it explores the equilibrium outcome of ostracism as a two-stage voting process wherein the decisive voter of the first stage may differ from that of the second.

The paper is structured as follows. Section 2 describes the historical background of the introduction of ostracism and the procedures followed when applied; it then reviews the ten attested ostracisms and surveys various modern interpretations of ostracism. Section 3 examines ostracism as the utility maximising choice of the constitution's writer at the time of

\footnotetext{
1 This is a fast expanding literature; the following studies are a representative sample: D'Amico (2010) for the development of law and order and specifically state prisons; Fleck and Hanssen (2006) for the extension of citizenship and the right to vote; Kaiser (2007) for financing the Athenian fleet; Kyriazis (2009) for public finance more generally; Lyttkens (2013) for Athenian collective choice institutions; McCannon (2010) for a game theoretic analysis of Socrates' trial; Ober (2008) for aggregation of private knowledge as an input to policy making; Pitsoulis (2011) for the adoption of majority voting; and Tridimas (2015a) for the fall of the Athenian democracy. Lyttkens (2013) considers that application of economic methodology to the Athenian democracy confers two important benefits as it helps to explain the ancient world: it enriches the understanding of the modern world by comparing it with historical societies, and it offers a better understanding of the uses and limitations of economic theory.
}

2 See footnote 1. 
its introduction. Section 4 presents a two-stage game theoretic model of ostracism and discusses the intuition gained by studying its equilibrium. It attributes the moderate application of the procedure to the utility maximising choice of the decisive voter of the first stage rather than appealing to any normative or ideological principles. Section 5 concludes.

\section{Historical context and interpretation}

\subsection{Origin of the Athenian ostracism}

In the archaic period, 750-500, before the establishment of democracy, political contests and competition for policy making authority in the Greek city-states were characterized by violent conflict amongst rival elite factions, whose status depended on control of the land, with rather limited active participation by the non-elite, poorer classes of the population. These contests resulted in a cycle of destruction and instability wherein the winning side expelled the losing side without any limits on the number of those expelled or the duration of their exiles. In turn, those expelled sought to return, sometimes in alliance with enemies of the polis, defeat and exile the rival incumbents, and so on, in what Forsdyke $(2000,2005)$ calls "the aristocratic politics of exile".

Despite attempts by Draco in 621, and Solon in 594 to normalize political life by establishing laws regulating access to political power, Athenian politics were typical of this pattern. In 546, after his third attempt, Peisistratus established tyranny, but contrary to the earlier norm, he allowed his rivals to stay in Athens and even hold public office, while also gaining popularity among the non-elites with a range of policy measures that benefited the poorer Athenians. However, under Hippias, Peisistratus' son and heir, violent aristocratic clashes resumed, as Hippias abandoned his father's practices and imposed a harsh rule. He was eventually overthrown in 510 and exiled. A struggle for control followed. In 508, the aristocrat Isagoras seemed to gain the upper hand against Cleisthenes, another aristocrat, who in response allied himself with the non-elite demos. Isagoras then requested the help of the Spartans, who in 507 invaded Athens. Cleisthenes was forced to flee along with another seven hundred families in a typical form of the politics of exile. But when the Spartan expeditionary force attempted to remove the government and restore Isagoras, the Athenian masses rose up and besieged them. The Spartans withdrew, Isagoras and those of his supporters who did not escape were executed and Cleisthenes and the rest of the exiles were recalled. Cleisthenes introduced a number of constitutional changes that reflected the new balance of power between the elites and the citizens, setting the foundations of democracy. ${ }^{3}$ They included the creation of a new tribal system that eliminated earlier geography-based divisions of the Athenians, a revised definition of citizenship, the transfer of policy making powers from aristocratic councils to the Assembly of the Demos, the establishment of the Council of Five Hundred to assist the Assembly, ${ }^{4}$ and the law on ostracism (Aristotle, Athenian Constitution, 22.1). ${ }^{5}$

\footnotetext{
${ }^{3}$ For the establishment of the Athenian democracy, see, amongst others, Lyttkens (2013) and Ober (2008) and the references therein.

4 The Council was responsible for preparing the agenda of the assembly, sorting out the matters to be discussed, and carried out the day-to-day administration of the state. Its members were chosen by lot and served for one year.

${ }^{5}$ I follow Kagan (1961) and Ostwald (1988), who dismissed doubts that Cleisthenes was the author of the ostracism law. Athenian ostracism was an elaboration of a more generalised Greek practice of using written ballots to determine a penalty-like removal from office or exile.
} 
The institutional arrangements of the Athenian democracy differed fundamentally from those of modern democracies. In a modern representative system of government, political parties propose policy platforms to the electorate and then compete for votes. Voters vote for political parties and choose candidates for office. The election winner has a mandate to govern and pursue her proposed policies. The outcome of the election contest depends on the proposed policies as well as on valence-non-policy issues like the personality of the candidate and her perceived competence. On the contrary, the Athenian system of government had no recognizable political parties competing for office, nor did it have a permanent bureaucracy to administer policy. Voters chose policies directly, not individual candidates (with the notable exception of the ten generals elected to lead the army in times of war). Whereas in modern practice the government initiates legislation, in Athens it was private citizens who brought issues for discussion to the Council; political leaders did not propose legislation in any official capacity. After its own deliberation, the Council brought the issue to the assembly (either as a specific decree already passed by the Council, or as an open issue) to be discussed and voted upon. The assembly voted after listening to the speeches for and against the motion. Implementation of the policy measures was then the responsibility of the Council, and, if applicable, specially appointed committees of magistrates. It is understood that the Athenians were a demanding audience, often booing and jeering public speakers (Hansen 1999). Almost inevitably, those with a talent for oratory or rich enough to be trained in rhetoric were the most frequent public speakers; as a result their views on policy issues became well known. The political leaders won or lost assembly votes on proposed policies, but did not win or lose office in the modern sense. A political leader could not be voted out of office (this was true even for those elected to the post of general to command the military, since generals were "in office" only during military campaigns).

\subsection{The process of ostracism}

The process of ostracism differed from passing ordinary legislation through the assembly. Each year, sometime in late December to early February, at a designated meeting, the presiding officer of the assembly of citizens called those attending the meeting to decide whether an ostracism vote would be held. This was a self-standing procedure; no names were mentioned in the call, nor was there a debate about it. The assembly then voted by show of hands whether they wanted an ostracism to take place. According to Hansen (1999, pp.130-132), in the fifth century perhaps 3000 Athenians turned up in assembly meetings, but attendance was higher in the fourth century when a quorum set at 6000 (about one-fifth of the population) had to be met and the first 6000 comers were paid for attendance (ibid). If a majority was in favor of holding one, the actual ostracism vote took place shortly afterwards: each citizen could cast a ballot in the form of a potsherd (ostrakon) on which the name of the person he wanted banished was inscribed. ${ }^{6}$ The potsherds were counted and if a minimum of 6000 had been submitted, they were sorted by names; the person with the highest tally (that is, plurality rather than overall majority) was banished for ten years. Only one person could be ostracised in any given year. Ostracism did not follow a penal trial; neither prosecution nor defense speeches were allowed before the

\footnotetext{
6 The timing is crucial: During the winter months the labor demands of agricultural activity were less urgent, affording Athenians from rural areas the time to congregate in the city center for casting their ballots. Note also that a two-stage procedure has the advantage of allowing a cooling-off period that avoids rash decisions, while it also offers the interested factions the opportunity for campaigning.
} 
second vote. The person ostracized had to leave Athens, at the latest ten days after the vote, and reside at a specific distance away from the city-state. However, apart from forcing the person away from the Athenian political scene, no other punishment was inflicted on him or his family, and he kept all his property. Ten years is not an insignificant proportion of one's adult lifetime, implying that a political leader returning from ostracism might have found few opportunities to become again politically influential. However, as it is described below, examples exist of ostracised leaders who at moments of crisis were recalled before the expiry of the 10-year period and re-entered active politics.

Thus, contrary to the forced mass exiles inflicted on the losing side by the winning elite in the violent politics of exile, ostracism administered moderate punishment, as it involved banishment for a limited period of time only of a single individual rather than his entire family and faction. ${ }^{7}$ For Plutarch, writing about four centuries after the last ostracism took place, "ostracism was not a penalty, but a way of pacifying and alleviating that jealousy which delights to humble the eminent, breathing out its malice into this disfranchisement". ${ }^{8}$ Given that the question of ostracism was put to the Assembly every year over two centuries of democracy, only a small number of ostracisms took place: ten are attested, and they all took place over the interval 487-416, something that may be interpreted as a remarkable moderation of the Athenians.

Several aspects of ostracism are noteworthy. To begin with, contrary to the assembly votes that were taken by show of hands, voter choices were written down, to ensure a formal and verifiable result. Remarkably, and in contrast to modern election practices where ballot papers are provided by the state, at the time each Athenian voter brought his own potsherd inscribed with the name of the person he wanted ostracized and could add his own brief comments on what he thought about the character of the person he wanted ostracized without invalidating his vote. ${ }^{9}$ To ensure secrecy, the inscribed side of each potsherd was supposed to be carried face down; however, secrecy was not always possible since scribes were often used by illiterate Athenians. What is more important from the perspective of the present study, ostracism was a two-round election, deciding the first stage with a simple majority vote and the second stage with a plurality (first-past-the-post) rule. Finally, it is worth stressing that control of the process of ostracism was in the hands of the demos, rather than any specific member of the elite. As no organized political parties existed, it was extremely difficult for any politician to organize a campaign to have his rival ostracized. Anyone who would have liked to see his opponent banished must have had realized that it was extremely risky to instruct his followers to call for an ostracism in the first stage of the vote, since he himself risked being ostracized at the second stage.

\subsection{Record of ostracism}

It is unfortunate that the precise numbers and dates of actual ostracisms are not fully certain. Hansen $(1999$, p. 35) mentions that 15 ostracism took place during the fifth century, but Forsdyke (2005, p. 164) writes, "We know of ten reasonably certain instances

\footnotetext{
7 The practice of ostracism was not confined to Athens only. Other Greek city-states, like Argos, Megara and Miletus, Syracuse and probably Ephesus, operated variants of ostracism; see Rhodes (1992, p. 93).

${ }^{8}$ Plutarch, Themistocles, 22.3; Plutarch makes similar comments in Aristides, 7.2; Alcibiades, 13.4; and Nicias, 11.1

9 "'Callixenus the traitor', ',Aristides, Lysimachus' son, spurner of the suppliants', and "'Xanthippus, Ariphron's son, is declared by this ostracon to be the out-and-out winner among accursed sinners"' (Hammond 1988, p. 524).
} 
Table 1 Known Athenian ostracisms. Source compiled from Forsdyke (2005)

\begin{tabular}{ll}
\hline Date ca. & Person ostracized \\
\hline 487 & Hipparchus, son of Charmus \\
486 & Megacles, son of Hippocrates (first time) \\
485 & Unnamed \\
484 & Xanthippus, son of Arriphron \\
482 & Aristides, son of Lysimachus \\
471 & Megacles, son of Hippocrates (second time) \\
470 & Themistocles, son of Neocles \\
461 & Cimon, son of Miltiades \\
442 & Thucydides, son of Melesias \\
416 & Hyperbolus, son of Antiphanes
\end{tabular}

of the actual expulsion of an individual through ostracism in the course of the almost two centuries that the institution was in force". Those instances are shown in Table $1 .{ }^{10}$ Details are better known for some but not all ostracisms. The reasons for ostracizing leading personalities seem to have varied over time and have related to foreign policy divisions and socioeconomic cleavages.

Ostracisms were distributed unevenly over time, with five ostracisms taking place in the 480s, necessitating some historical background for a better understanding. The first ostracism was carried out 20 years after the institution was introduced. "The "customary mildness of the people' toward the 'friends of the tyrants' is given as the only explanation of this peculiar delay" (Ostwald 1988, p. 334). According to Aristotle (Athenian Constitution, 22.6), the first three ostracisms banished "the friends of the [Peisistratid] tyrants". In the 490s, Athens was at war against the island of Aegina, which had acquiesced to Persia. In the 490 Marathon battle, the Athenians defeated the invading Persians, whose empire was expanding towards the Greek city-states and intended to reinstate Hippias as tyrant. In the following decade, Athenian politics was dominated by the policy towards Persia. Remarkably, the first ostracism coincides with the introduction of the lot in the selection of the nine Athenian archons circa 487-486, a reform that weakened the hold of the traditional elites on power. Selection to public office by lot (known as sortition) was an integral part of the Athenian democracy, as it offered equal opportunities to citizens to serve in public posts performing routine duties and receiving fees for services paid by the public purse (see Tridimas 2012 for a detailed analysis). The establishment of the Athenian democracy was a gradual process wherein the demos and most significantly the classes of free small landholders and landless citizens were empowered to participate in policy making and occupy public office, which before the democracy was the exclusive preserve of the elite. Thus, the first three ostracisms may be indicative of the divisions on policy towards the tyrants, Persia and democratic reforms. Invoking the law on ostracism gave the

\footnotetext{
${ }^{10}$ Excavations have now revealed the names of more than 130 Athenians against whom votes were cast during the years of holding ostracism votes. A large number of ostraca, referred to as 'scatter votes', bear the names of persons who are otherwise unknown. This is taken as an indication that the Athenians cast their votes against individuals for a variety of reasons, including excessive prestige, adultery, incest, religious offences and bribe-taking (Forsdyke 2005). A complementary view worthy of further investigation is that scatter ostraca are indicative of expressive voting, where voters realizing that they had no chance of affecting the ballot outcome voted in order to affirm their identity and used the opportunity to punish enemies rather than reward friends (for a survey of expressive behavior in economics and politics, and further references, see Hillman 2010).
} 
people an opportunity to decide whether opposition or accommodation with the Persians should be the official policy of Athens. ${ }^{11}$

Little is known about the ostracism of Xanthippus, apart from the fact that he was recalled to Athens before the end of his ten-year banishment (and so was Aristides; see below) on the eve of the Salamis sea battle of 480 and subsequently was elected general. Policy against Persia was most likely the reason for the next ostracism. Aristides objected the proposal of Themistocles to use the revenue from silver deposits newly discovered in 483-482 to build a navy to fight the Persians. ${ }^{12}$ According to Plutarch (Aristides, 3.2), Aristides was overheard saying one day, as he was leaving an Assembly meeting in which he had managed to prevent the passage of an important measure introduced by Themistocles, that there was no hope for the survival of Athenian interests, unless both he and Themistocles were to be thrown into the pit of ostracism. Ostwald (1988, p. 344) writes that, "Themistocles' naval policy could not have been implemented if it had been consistently exposed to the vigorous challenges of as strong a person as Aristides. Under the Athenian system only ostracism could decide-before it was too late-which of two or more mutually exclusive policies was to prevail." Nevertheless, in an act of unity before the external threat, Aristides later was recalled and fought against the invading Persians.

The division between the old aristocratic elites of landed wealth and ordinary citizens of lesser means lies behind the later ostracisms. Themistocles and Cimon differed both in their backgrounds as well as in their policies. Themistocles, of humble social origins and a visionary strategist, pursued policies opposed by Sparta (Athens' great Greek rival); Cimon, a rich aristocrat and able military commander, favored friendly relations with oligarchic Sparta. Themistocles was ostracized and later condemned to death for treason in supporting the Persians. Ten years later, in 462-461, Cimon tried to reverse a newly introduced democratic reform by Ephialtes, by which the Council of Areopagus, a remnant of aristocratic control that had overseen laws and conducted political trials, was reduced to a judicial body dealing only with homicide. Cimon was ostracized (but recalled later), while Ephialtes was assassinated. The ostracism of Thucydides (no relation to the celebrated historian), the political successor of Cimon, took place after Pericles, whose reforms and public spending programs benefited the poorer Athenians, was accused of financing the Athenian building program with the money collected from the Athenian allies. ${ }^{13}$ Pericles then remained unchallenged as the leading statesman, elected as general for 15 years without interruption. The last ostracism took place in 416, after two leading politicians, Nicias, supporting peace with Sparta in the Peloponnesian War, and Alcibiades, leading the warmongers, allegedly combined their followers to secure the banishment of Hyperbolus. ${ }^{14}$

\footnotetext{
11 "[I]t is conceivable that the advocates of resistance [against Persia], knowing that the presence of Hipparchus and Megacles [who advised accommodation with Persia] in Athens would undermine any serious effort at rearmament, invoked the law on ostracism to give the people an opportunity to decide whether resistance or accommodation should be the official policy of Athens. The fact that it took three successive ostracisms to curtail the influence of the 'friends of the tyrants' in Athens indicates how evenly divided the citizens were in their attitude[s] toward Persia, but also that the will to resist prevailed and did have a clear field after 485 BC" (Ostwald 1988, p. 342).

12 See Tridimas (2013) for a recent analysis of the disposal of the silver bonanza based on the methodology of the economics of conflict.

13 "Surviving ostraca of Pericles are very rare, and such evidence as we have, mostly from unpublished ostraca, suggests that Thucydides' supporters tried to concentrate their votes, not against him, but against Cleippides, only known from literature as general in 428" (Lewis 1992, p. 141).

14 "By the collusion of Nicias and Alcibiades this issue [of war against Sparta] was evaded, so that both were available as generals when a graver decision was made in 415 [to launch the Sicilian expedition which ended with the annihilation of the Athenian force]; and this was the end also of ostracism as a means of
} 
According to Plutach, realizing that the mechanism could be abused by collusion without resolving the rivalry that set the ostracism in motion, the Athenians were incensed and never voted for another ostracism again (Plutarch, Aristides, 7.3-7.4; Nicias, 11.5; see also Hansen 1999, p. 280). Nevertheless, in view of Hyperbolus' poor reputation (see Rosenbloom 2004a, b; Taylor 2007), the result was not particularly surprising. ${ }^{15}$

Before proceeding, it is worth noting some similarities between ostracism and the modern recall vote whereby voters may vote to remove an official from office before the end of her term. However, several important differences stand out: First, the recall is not a recurring annual vote, but is initiated by a petition of a required minimum number of voters. In Athens, on the other hand, a statute required holding annually the initial vote on whether or not an ostracism vote would take place later during the same year. Second, the recall removes an official holding a public post, while the ostracism could be directed against any private citizen. Third, the recall vote is followed by a vote to replace the official thrown out from a list of declared candidates. In the case of the actual ostracism vote there was no list of candidates to choose from. That is, in a recall vote only those interested in office may be elected, while in the ostracism vote any prominent individual was at risk of being ostracised.

\subsection{A review of modern interpretations of ostracism}

Modern scholars differ in their interpretations of ostracism. Following the assertion of Aristotle in the Athenian Constitution that the motive behind the law of ostracism was suspicions that men of wealth and power may become tyrants, Kagan (1961) considers it as the instrument that would enable Cleisthenes to deprive those favoring tyranny of their leaders (because full destruction of their faction would not have been possible and would have provoked retaliation). More recent research rejects the interpretation of ostracism as a deterrent for would-be tyrants, arguing that the assertion of the Athenian Constitution to the opposite was the result of a later invention, because laws against those attempting to establish tyranny were available in the statutes from the time of Solon, well before the establishment of democracy and provided for severe penalties. Ostwald (1988, p. 442) thought of ostracism as a mechanism for deciding policy issues. ${ }^{16}$ Similarly, Andrewes (1992) viewed "ostracism as a means of choosing between two policies which had nearly equal and dangerously heated support." The same view likewise is supported by Cartledge

Footnote 14 continued

choosing between two policies which had nearly equal and dangerously heated support.... [As] decisions about [foreign policy] went in Alcibiades' favour, it looks as if Alcibiades could safely have risked a straight contest with Nicias in the ostracism and the compact against Hyperbolus not only left important issues unresolved but had a damaging effect on the rest of Alcibiades' career" (Andrewes 1992, p. 442).

15 During the fourth century, the mechanism most often used against political leaders was an impeachment trial known as eisangelia. That is, a court tried the elected generals for the crimes of attempting to overthrow the constitution, treason or corruption after the Assembly had referred such a case to it. In addition, the court reviewed the constitutional validity of the decisions of the Assembly (called "graphe paranomon"); the court had the power to annul a decree and punish its proposer. Given that the Athenians never repealed the law on ostracism, and contrary to Hansen's (1999) view, Forsdyke (2005) doubts that prosecution for unconstitutional laws was consciously used to replace ostracism.

16 "Under the Athenian system only ostracism could decide... which... policy was to prevail.... The Athenians solved the problem of a possible policy-deadlock in the state not by killing or permanently exiling the proponents of an unpopular policy, as the tyrants had done, but by establishing a due process through which the people as a whole would decide which of two or more opposing policies should be given the chance to develop fully into the policy of the state" (Ostwald 1988, p. 344; emphasis in the original). 
(2006, pp. 3, 5), arguing that ostracism was "probably introduced to prevent deadlock in public decision-making, when the Athenian voters were faced with a choice between programmes and their champions that were too evenly matched for comfort" and "it was not primarily a way of removing individuals from formal public office, but rather of making decisions over the policies and leadership of political factions".

On the other hand, Forsdyke $(2000,2005)$ views ostracism as a form of conflict resolution that eliminated the violence from intra-elite political contests of the archaic period, ended the destabilizing effect of such contests by limiting expulsion to one individual only rather than of his entire family and followers, and asserted the rule of the demos over earlier rule by the elite. She adds further that with the passage of time it served as a continual symbolic reminder to the aristocracy of the supremacy of the demos (for it is doubtful that the banishment of a single individual would prevent the outbreak of violence). Furthermore, she refutes the use of ostracism as a means of resolving policy disputes, since that was the task of the assembly of the demos. She posits that the ostracisms of Aristides, Cimon and Thucydides showed that resort to the mechanism was made at moments of sharp conflict between political leaders and their supporters, while, given the numbers of citizens involved, she finds it unlikely that the elites could manipulate the votes against Hyperbolus. She goes on to discredit the view that ostracism was designed as a weapon against traitors or against potential tyrants, since special legislation was in place for such crimes against the state. ${ }^{17}$ Finally, she attributes the infrequent use of ostracism to the symbolic and moderate nature of the mechanism (designed to ensure exile for limited periods of time only) and, on account of the small number of actual ostracisms imposed, she argues that it actually stabilzed Athenian politics. Forsdyke's view that an ostracism vote did not resolve political disputes between different leaders implicitly assumes that political competition always took the form of a united demos against the elite. This conception, however, breaks down if one considers that the demos were not always united and that different citizens might have supported different leaders.

Taylor (2007) shows that it was the wealthy elite who were at most risk from ostracism, while the political prominence and notoriety of the individual also were relevant. Partly echoing Forsdyke, Ober $(2008,2015)$ sees ostracism as an accountability mechanism that defended the demos against the threats of civil conflict and elite capture by confirming its direct and decisive involvement in the government of the polity. Furthermore, since citizens cast their ballots without hearing speeches or other deliberations, he interprets the mechanism as focusing on expected future benefits and costs from the involvement of an individual in future political decision making, rather than as a punishment for past actions (although a person's past record could be used to form expectations about his future conduct).

Rosenbloom (2004a, b) also sees ostracism not just as a political procedure but a "symbol-laden activity", but, contrary to Forsdyke, considers it as a contest for political dominance. He argues that an individual who was subject to the ordeal of ostracism signalled his worthiness for political leadership and surviving it proved his worthiness. Focusing on the ostracism of Hyperbolus, he rejects Plutarch's narrative that the ostracism vote of 416 was a struggle between Nicias, who recommended peace with Sparta, and Alcibiades, who pushed for war. He argues that the underlying cause of the ostracism of Hyperbolus was a dispute between two groups of political leaders. The first group

\footnotetext{
17 "Traitors, for instance, were required to stand trial in Athens and, if convicted, condemned to death or banished for life, with total loss of property and loss of the right to burial in the territory of the polis. Tyrants were either condemned to death or banished from the polis for life along with their family, and their property was confiscated by the state" (Forsdyke 2000, pp. 254-255).
} 
consisted of members of the noble, land-holding families, the traditionally hegemonic faction (even though different members promoted different policy agendas), represented by Nicias and Alcibiades. The second group consisted of those whose wealth was based on commercial activities like manufacturing and trade. Vying for social recognition and political acceptance, Hyperbolus, a member of the latter group, initiated the ostracism contest hoping to survive it so that, like earlier survivors, he could claim political leadership. His failure, however, indicated that a strong bond still existed between the traditional elites and the demos who rejected his pretensions. Rosenbloom then attributes the subsequent abandonment of ostracism to the prominence achieved by the newly wealthy class of manufacturers and traders, who pursued their politics through the courts, ${ }^{18}$ instead of the elected office of general.

In sum, the more recent literature contends that ostracism was neither a method of punishment of political leaders, nor of getting rid of one's political opponent, nor of implementing the favorite policy of a politician. Punishing politicians for treason, corruption and attempts to establish tyranny was pursued through the courts. A leader trying to use the mechanism to eliminate an opponent risked becoming the victim. Policy issues were decided in the assembly. Cleisthenes, the architect of the ostracism mechanism, designed a new way of conducting politics, a method of resolving peacefully contests for power between political leaders according to the wishes of the demos.

\section{Conflict, ostracism and the choice of the constitutional writer}

Missing from the previous interpretations of ostracism is an explicit account of why in 508-507 Cleisthenes, a political leader with the authority to write the constitution, chose to introduce ostracism to resolve political contests rather than continuing the politics of violent conflict and exile. This is done in the present section by using a simple model drawn from the economics of conflict, ${ }^{19}$ wherein the constitutional writer is assumed to select the structure that maximizes his expected payoff.

\subsection{Payoff from violent conflict}

Assume a political leader $i$, heading his own faction of followers with private income $Y_{i}>0$, and let $R_{i}>0$ denote the net rent that can be had if he wins power. A word is first needed to clarify the meaning of rent. Contrary to the modern practice, in sixth century Athens the holders of public office received no remuneration from the public purse. Ruling (or "archein") meant to exercise power that secured access to resources, and thus to financial benefits, prestige and security for one's family, retinue and followers. It is these benefits that are represented by $R_{i}$. Stylistically, the right to exercise power is conferred on the winner of a violent contest between rival political leaders, typically heads of aristocratic families. Note that, in general, net office rents $R_{i}$ differed in size across individual

\footnotetext{
${ }^{18}$ Unlike the ostracism vote, a trial of a distinguished citizen before a jury makes high status and family wealth an asset, for it can buy the services of an advocate-an orator to convince the jury to acquit. This argument broadly corroborates Lyttkens' (2013) view that in the fourth century BCE partial redistribution of powers from the Assembly to the courts (where the rich could be more influential), signified an increase in the political influence of the rich.

19 See Garfinkel and Skaperdas (2007) for a survey of the literature; see Tridimas (2013, 2015a) for applications of the methodology to the wars of ancient Athens.
} 
political leaders. Two reasons account for that. First, different individuals may value office rents differently. Second, the "logic of collective action" (Olson 1965) implies that private agents may not organize spontaneously to pursue a common interest, so that political leaders have to offer private inducements to potential followers to form effective fighting groups. Depending on circumstances, different leaders may adopt different rent-sharing formulas, resulting in different net rents for each leader. Let $P$ denote the probability that a political leader wins a violent contest for power; as is well known from conflict economics, $P$ too varies across different individuals. Irrespective of its outcome, fighting costs a sum $G_{i}>0$, which is defined to include military expenditure and the cost of acquiring the expertise to administer public affairs, and may well vary across different persons depending on their characteristics, personal circumstances and abilities to organize their followers militarily. Furthermore, let $G_{i}$ be a proportion $g_{i}$ of income, i.e., $G_{i}=g_{i} Y_{i}, 0<g_{i}$. Finally, violence is assumed to destroy a fraction $\phi$ of material wealth, income and rents. ${ }^{20}$

The individual loses the conflict with probability $1-P$, in which case he loses all of his private income. The expected payoff from the political conflict game is $U_{i}^{C}=P(1-$ $\phi)\left(Y_{i}+R_{i}\right)-g_{i} Y$ or, more compactly,

$$
U_{i}^{C}=P(1-\phi) R_{i}+\left(P(1-\phi)-g_{i}\right) Y_{i}
$$

Intuitively, given the income of an individual, the benefits from seeking political power are smaller the larger the cost of conflict $g_{i}$, the larger the destruction rate $\phi$, the smaller the probability of winning the contest $P$ and the smaller the rents $R_{i}{ }^{21}$

\subsection{Payoff from majoritarian politics with ostracism}

In the democratic politics inaugurated by Cleisthenes, political leaders competed for rents peacefully. Let $Q$ denote the probability that a political leader $i$ wins the assembly vote and implements his favorite policy, which yields him a rent $R_{i}$ as before, and let $F$ denote the probability that he is not ostracized. If he loses the assembly vote (an event that occurs with a probability of $1-Q$ ), or if he is ostracised (an event occurring with a probability of $1-F)$, he receives no rent. In contrast to the previous case of violent conflict, in the electoral contest no income is destroyed, and the political leader retains his income even if he is ostracized. However, ostracism carried a certain disutility associated with the inconvenience of being forced to leave Athens and possible loss of prestige, so we model ostracism as resulting in a smaller private income equal to $(1-w) Y_{i}, \quad 0 \leq w<1$. Parameter $w$ can therefore be thought of as representing fine-grained aspects of "punishment" from ostracism. Finally, it is assumed that fighting a political contest for votes costs $X_{i}$ which is a proportion $x_{i}$ of income. Hence, $X_{i}=x_{i} Y_{i}, 0<x_{i}$, where $X_{i}$ consists of the costs of garnering popular support, which includes paying for a variety of public services, ${ }^{22}$

\footnotetext{
${ }^{20}$ It bears noting that the material damages and the human costs associated with violent contests for power affected not only the combatants, but more generally spilled over to groups not involved directly in the competitions, since aristocratic families vying for control stood at the apex of a pyramid of groups of people bound to them by blood, kinship, economic and other ties.

21 The simple model analyzed here is in some way extreme, for it abstracts from the possibility that the loser may not lose all his income (especially if that income is generated from sources outside Athens) and may therefore launch another bid for power in the future, as was sometimes the case.

22 These payments became known as "liturgies". They related to financing festivals, like raising choirs, or troops of runners for various competitions, or paying for theatrical performances, and the trierarchy, that is,
} 
acquiring the rhetorical skills necessary to win assembly debates and the expertise required for administering public affairs. As before, such costs are assumed to vary across different individuals, because, for example, politicians differ in their attractiveness to the demos. The payoff from the peaceful voting game with ostracism is $U_{i}^{O}=F\left(Q\left(Y_{i}+R_{i}\right)+(1-\right.$ $\left.Q) Y_{i}\right)+(1-F)(1-w) Y_{i}-x_{i} Y_{i}$ or, more compactly,

$$
U_{i}^{O}=F Q R_{i}+\left(1-w(1-F)-x_{i}\right) Y_{i}
$$

The expression $F Q$, the product of the probability of not being ostracised times the probability of winning the vote, represents the conditional probability of winning power under democracy. Intuitively, in order to prevail a political leader confronts a double constraint of winning at the assembly and being acceptable to the citizenry. This structure implies that only leaders who marshal the political support of more than a simple assembly majority will be successful.

\subsection{The choice of the constitutional framer}

The constitutional framer introduces a majoritarian political contest with ostracism when $U_{i}^{O}>U_{i}^{C}$, that is, when the expected payoff from adopting the ostracism process is greater than the expected payoff from a violent confrontation. ${ }^{23}$ Comparing (2) and (1), we obtain.

$$
U_{i}^{O}-U_{i}^{C}=(Q F-P(1-\phi)) R_{i}+\left(1-w(1-F)-P(1-\phi)+g_{i}-x_{i}\right) Y_{i}
$$

The difference $Q F-P(1-\phi)$ represents the net probability of winning power through democratic politics rather than through violent confrontation; it has an ambiguous sign. Thus, the first component of the sum on the right-hand side of (3) signifies the expected net value of winning political power peacefully. Other things being equal, a political leader with the right to write the constitution introduces majoritarian politics with ostracism as a form of conflict resolution if he expects the conditional probability that he avoids ostracism and succeeds in winning the assembly vote, $F Q$, to be greater than the probability of winning a violent conflict $P$. The expression $1-w(1-F)-P(1-\phi)$ shows the fraction of income saved by not engaging in violent conflict; although its sign depends on the exact parameter values, we reasonably may expect it to be positive, especially when $w$ is small. The expression $g_{i}-x_{i}$ shows the net cost of violence as a share of income; its sign is positive (negative) when violent conflicts cost more (less) than assembly politics. Thus, the term $\left(1-w(1-F)-P(1-\phi)+g_{i}-x_{i}\right) Y_{i}$ represents the expected net value of private income from peaceful politics. When a political leader expects that voter support garnered by his oratory and provision of public services costs him less than fighting a violent campaign against his rivals, he will choose democratic politics. In the opposite case, he is better off in an ex ante sense by the continuation of politics by violent means. From Eq. (3) it also is obvious that the greater is conflict's destruction rate and the smaller is the probability of winning the violent power contest, the more likely it is that the constitution's framer will choose political rivalry with ostracism.

Footnote 22 continued

the command, outfitting and maintenance of a trireme for one year. For an overview of liturgies, see Lyttkens (2013) and Tridimas (2015b).

${ }^{23}$ For an individual $i$ to seek power through violent confrontation and through majoritarian politics with ostracism it must be $U_{i}^{C}>Y_{i}$ and $U_{i}^{O}>Y_{i}$, respectively. That is, his expected payoffs from the two mechanisms must be higher from his private income; otherwise, he has no incentive to participate in the quest for power. In what follows it is assumed that these inequalities always hold. 
In sum, any individual aspiring to political power who believes that he is more likely to achieve political power by winning debates and convincing the demos of his administrative abilities will accept a majoritarian and peaceful conflict resolution mechanism, provided that the risk of being ostracized is sufficiently small. Only those who consider themselves to be better fighters than debaters, i.e., incur lower costs of winning violent contests than of garnering the support of assembly majorities, will favor the former option.

It appears that the previous conditions favoring introduction of majoritarian politics with ostracism were met in the case of Cleisthenes. As a member of the Alcmeonid aristocratic family, whose fortunes had waxed and waned during the seventh and sixth centuries BCE, he had direct experience of the personal and private losses involved in conflict and was conscious of the small probability of winning violent confrontations. At the time of the expulsion of Isagoras he must have enjoyed considerable popularity. It is not then surprising that he opted for politics rather than violence, especially since he must have been almost certain that he would not be ostracized. This conclusion ties well with the view of Cleisthenes as the "incidental democrat". ${ }^{24}$ That is, rather than being a great visionary working on a grand plan to give power to the people, Cleisthenes was a political leader interested in maximizing his own payoffs. However, by seeking support from the common people in his intra-elite fight, he unleashed political forces that could not be contained before full democracy (for male citizens) was established. This analysis is also consistent with Aristotle's statement in Athenian Constitution (22.3-4) that ostracism was introduced as a precaution against potential tyrants because Cleisthenes wanted to drive Hipparchus, a relative of the Peisistratus, out of Athens.

Moreover the introduction of ostracism as a mechanism to resolve peacefully conflicts between political leaders (by identifying who commanded the least popular support) goes hand-in-hand with the adoption of majority rule that materialized with the Cleisthenes' reforms. Beginning in the seventh century $\mathrm{BCE}$, changes in the technology of warfare rendered the hoplites, heavily armed citizens, as the decisive factor on the battlefield. ${ }^{25}$ In consequence, it became impossible to deny citizens participation rights in collective decision making, a development that eventually replaced the risk of actual fighting between citizens in the city-state with headcounts of people supporting different proposals, that is, majority voting. In the struggle for control, Cleisthenes "attached the people to his following to give political power to the masses... and became leader and champion of the people" (Athenian Constitution, 20); the adoption of ostracism was a constituent element of the new majoritarian constitutional rules.

As the democracy matured, ostracism's potential value in resolving political crises must have been recognised. Since the Athenians practiced direct democractic voting on policy issues rather than choosing political representatives, no electoral way of revealing citizens' confidences in politicians existed. Neither was an effective mechanism available to stop a leader and his associates from bringing the same issue up for debate again. Conceivably, if no clear policy winner had emerged from the normal business of politics in the assembly, a risk of violent conflict to resolve the stalemate emerged as the interested actors each would try to secure their preferred outcome and the corresponding gains. Political standoffs and high tensions were detrimental to the polis. In such circumstances, the process of ostracism offered a peaceful and hence less costly alternative for relaxing political tensions by ascertaining the extent of popular support for a particular political leader. It was a negative

\footnotetext{
${ }^{24}$ For an examination of Cleisthenes as a rational, self-interested political actor, see Tridimas (2011) and Lyttkens (2013, pp. 59-64 \& 83-88) and the references cited therein.

25 See Pitsoulis (2011) and the references therein for a detailed discussion of the origins of majority voting.
} 
referendum on persons rather than on specific policy issues. As a corollary, the foregoing account illustrates that ostracism was an early example of the "law of unintended consequences"; it was introduced to resolve conflicts at the end of the sixth century, but the procedure was then used for resolving other political questions.

\section{Equilibrium outcomes in ostracism votes}

Ostracism was different from the standard assembly votes on policy questions as it involved a two-stage decision game. ${ }^{26}$ In the first stage of the game, the assembly of the demos decided whether or not an ostracism vote would take place. If the majority vote was "nay", the game ended. If the vote was "aye", the second stage was played, wherein citizens marked the potsherds with the name of the person they wanted ostracized. Potsherds were then counted and the person receiving a plurality of the votes was expelled from Athens. Recalling that any one of the political leaders, or eminent Athenians, $j=$ $A, B \ldots N$ may be banished, Fig. 1 shows the extensive form of the game.

Comparing the two stages, we observe that the ostracism vote at the first stage: (1) was taken among those who attended the relevant assembly meeting; (2) asked a simple question, yes or no, to holding an ostracism vote; and (3) required a simple majority. On the other hand, the vote at the second stage: (1) was taken among the entire eligible citizenry (allowing participation by those residing away from the urban center where the assembly took place); (2) was an open vote on any person whose name the citizens wrote on the potsherds; and (3) required only a plurality of votes. In view of those differences, it is reasonable to presume that the decisive voter at the first stage was different from the decisive voter at the second stage.

Like all elections that apply simple majority or plurality, the ostracism vote was vulnerable to strategic (insincere) voting. In the first ballot "to hold or not to hold an ostracism vote", a voter may vote strategically against holding an ostracism vote because he worries that his most preferred politician (or even himself) may be ostracized at the second stage. ${ }^{27}$ Specifically, assume two politicians denoted by $A$ and $B$ ranked by voter $i$ as $A<B$. Voter $i$ would like to see $A$ ostracized but if he worries that $B$ may be ostracized instead, he votes against holding an ostracism vote. At the second stage deciding "who to ostracise", a voter may again vote strategically by choosing to ostracise a less disliked politician in order to prevent the banishment of a more liked politician. Specifically, assume three politicians denoted by $A, B$ and $C$ ranked by voter $i$ as $A<B<C$. The voter prefers to see $A$ ostracised, but if he thinks that the chance of this happening is remote, he votes strategically by marking $B$ for ostracism. A voter is less likely to vote strategically, the more intensely he prefers a policy or a candidate, the more partisan he is, and the less sophisticated he is, that is, the less able he is to predict which candidate will come third, a factor that correlates with his level of education and income (Shaw et al. 2005). In modern plurality elections the extent of strategic voting is examined by scrutinising detailed voter responses in opinion polls, something that obviously is not possible for ancient Athens. As a corollary, any political leader will approach the ostracism vote cautiously. Calling for ostracism at the first stage in order to have an opponent banished may backfire. Voters at the second stage may vote to banish the proposer himself or a political friend of his.

\footnotetext{
${ }^{26}$ In ancient Athens a two-stage decision structure was a common format of collective decision making; it was also was used in the Athenian legal system. See McCannon (2010).

27 Alvarez and Kiewiet (2009, p. 283) refer to this type of voting as "conditional hedge voting". .
} 
Fig. 1 The two-stage procedure of ostracism vote

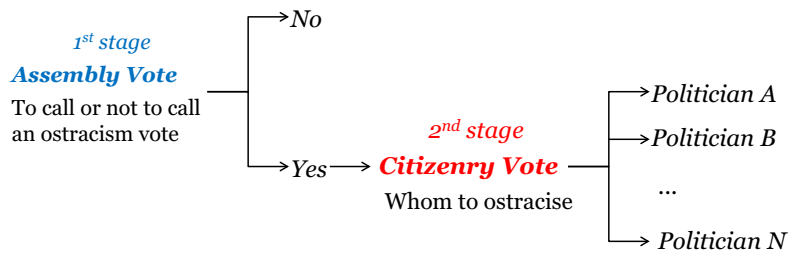

\subsection{The vote for ostracism in a two-stage voting process}

We now explore the equilibrium outcome of the two-stage ostracism game. Let each voter have Euclidian preferences regarding political leaders. That is, he has an ideal type of politician that he would like to see in charge of the affairs of the state. The ideal may combine policy issues, talent and other personal qualities ascribed to leaders. We assume that the type of leader is a single-dimensional issue, so that different types can be arrayed on a line from left to right and normalized on a $0-1$ scale. Let $v_{i} 0 \leq v_{i} \leq 1$ denote the ideal type of political leader for voter $i$. In general, actual leaders, denoted by $j=A, B, \ldots, N$ differ from the ideal type. The utility of voter $i$ is written as $u_{i}=-\left(v_{i}-j\right)^{2}$. Analytically, the closer an actual political leader is to the voter's ideal type, the larger is the voter's payoff. Furthermore, the voter is indifferent between politicians who are equidistant from his ideal point (either to the left or to the right). For concreteness, it is now assumed that voters choose between two political leaders only $A$ and $B$. Voter $i$ ostracizes political leader $A$ instead of $B$ when the payoff from $A$ 's presence on the political scene is less than the payoff from the presence of $B$, formally $-\left(v_{i}-A\right)^{2}<-\left(v_{i}-B\right)^{2}$. Let $M_{1} \in[0,1]$ and $M_{2} \in[0,1]$, respectively, denote the ideal politician types of the decisive voters of the first stage and second stage.

Given the political setting of Athens described above, $M_{1}$ is the median voter of the assembly with regard to the question of "shall there be an ostracism vote?" It bears noting that $M_{1}$ may not be the decisive voter with respect to policy on a specific issue, since the latter depends on policy positions rather than types of politicians. $M_{2}$ is the decisive (swing) voter in the second- stage plurality election (see Persson and Tabellini 1999) where the political leader to be ostracised is named. Again, $M_{2}$ may not be decisive for a policy issue. Nor is there any particular relationship between $M_{1}$ (or $M_{2}$ ) on the one hand, and $A$ and $B$ on the other. Most importantly, since the decisive voter in the assembly differ from the decisive voter in the electorate-wide ostracism vote, we have $M_{1} \neq M_{2}$.

\subsection{Second stage vote}

The ostracism game is solved by backward induction starting from the second stage. For concreteness, assume again that voters choose between two political leaders only $A$ and $B$ (in which case, the strategic voting problem from the second stage is eliminated), and a pivotal second stage voter can be identified easily. We then have that if politician $B$ is ostracised and politician $A$ remains active in Athenian politics, the payoff of the decisive second stage voter is $V_{2}^{O B}=-\left(M_{2}-A\right)^{2}$; if $A$ is ostracised and $B$ remains, the decisive voter's payoff is $V_{2}^{O A}=-\left(M_{2}-B\right)^{2}$. The decisive voter votes to ostracise $A$ when retaining B yields a higher payoff, that is, $V_{2}^{O A}>V_{2}^{O B}$ or $\left(M_{2}-A\right)^{2}>\left(M_{2}-B\right)^{2}$. On the other hand, $M_{2}$ ostracizes $B$ when the inequality is reversed. Analytically, the decisive 
Fig. 2 Ostracism at the second stage

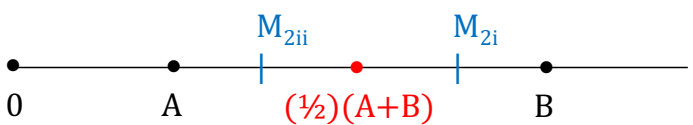

(1) $0<\mathrm{A}<\mathrm{B}$ : A is "moderate":

(i) with $M_{2 i}>(1 / 2)(A+B) \Rightarrow A$ is ostracised

(ii) with $\mathrm{M}_{2 \mathrm{ii}}<(1 / 2)(\mathrm{A}+\mathrm{B}) \Rightarrow \mathrm{B}$ is ostracised

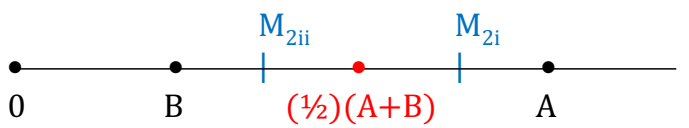

(2) $0<\mathrm{B}<\mathrm{A}$ : A is "extreme":

(i) with $M_{2 i \mathrm{i}}<(1 / 2)(A+B) \Rightarrow A$ is ostracised

(ii) with $M_{2 i}>(1 / 2)(A+B) \Rightarrow B$ is ostracised

voter ostracizes the political leader $A$ or $B$ whose ideal point lies furthest away from $M_{2}$. Rearranging we have

$$
V_{2}^{O A}-V_{2}^{O B}=(B-A)\left(2 M_{2}-(A+B)\right)
$$

There are two cases to consider, (1) when $0<A<B$, in which case $M_{2}$ can be thought as seeing $A$ the "moderate" type in comparison to $B$; (2) when $0<B<A$, in which case $M_{2}$ sees $A$ as the "extreme" type of political leader. We then have

- When $0<A<B$ and $M_{2}>\frac{1}{2}(A+B), A$ is ostracised

- When $0<A<B$ and $M_{2}<\frac{1}{2}(A+B), B$ is ostracised

- When $0<B<A$ and $M_{2}<\frac{1}{2}(A+B), A$ is ostracised

- When $0<B<A$ and $M_{2}>\frac{1}{2}(A+B), B$ is ostracised

The sets of the stated conditions are shown graphically in Fig. 2. That is, what matters for the decision to ostracise is the position of the decisive voter relative to the positions of the means of the two leaders. ${ }^{28}$

Under a plurality voting rule, the politician with the largest number of votes is banished with more than one ostracism candidate. Without further information about the factors that influence voters to want to remove a politician from the scene, it is no longer straightforward to write down the algebraic solution for ostracism. It nevertheless is intuitively clear that the majoritarian voting system will ostracize the politician with the largest vote tally (however, as we know from collective choice theory, the "winner" of that vote may not be the Condorcet winner from all pair-wise comparisons).

\subsection{First-stage decision}

Now we consider the vote of the assembly at the first stage of the process. The decisive assembly voter, $M_{1}$, knows that if he chooses to support an ostracism vote, he will not be decisive in the second stage vote regarding who is ostracized. He may then not vote to move to the second stage as a hedge against an ostracism result that he wishes to avoid. We

${ }^{28}$ It bears noting that the outcome does not depend on whether $M_{2}$ lies between points $A$ and $B$ as drawn in Fig. 2. The same result holds when $M_{2}$ is to the left of $A$ or to the right of $B$ in Fig. 2.1 and, similarly, to the left of $B$ or the right of $A$ in Fig. 2.2. 
model $M_{1}$ 's uncertainty about the second stage outcome as follows: He attaches a probability $0 \leq \Pi \leq 1$ to the event that $M_{2}$ ostracises political leader $B$ and a probability $1-\Pi$ to the event that $M_{2}$ ostracises political leader $A$. Equivalently, $\Pi$ (analogously, $1-\Pi$ ) is the probability that $A$ (analogously, $B$ ) remains active in Athenian politics. Thus, if $M_{1}$ supports an ostracism vote, his expected utility is

$$
V_{1}^{O}=-\Pi\left(M_{1}-A\right)^{2}-(1-\Pi)\left(M_{1}-B\right)^{2}
$$

On the other hand, if $M_{1}$ does not vote for ostracism, both $A$ and $B$ remain active participants in Athenian politics. Pivotal voter $M_{1}$ evaluates the simultaneous presence of $A$ and $B$ as a type of a composite politician $K$ represented by the weighted average $K=$ $S A+(1-S) B$, where $S$ is a simultaneous presence scalar, such that $0 \leq S \leq 1$. More concretely, $S$ can be interpreted as the frequency with which the type $A$ politician wins assembly votes on policy issues. Analogously, $1-S$ denotes the frequency that the type $B$ politician leads Athenian politics. The payoff of $M_{1}$ from the presence of both $A$ and $B$ in Athenian politics (equivalently, not calling for an ostracism vote) is then written as

$$
V_{1}^{N}=-\left[M_{1}-(S A+(1-S) B)\right]^{2}
$$

$M_{1}$ votes for (against) an ostracism vote to take place when his expected payoff from either $A$ or $B$ being banished is greater (smaller) than the payoff when both leaders remain politically active, that is, $V_{1}^{O}>(<) V^{N}$. Denoting $\Delta \equiv V_{1}^{O}-V_{1}^{N}$, substituting from (5) and (6) and manipulating we have

$$
\Delta=(B-A)\left[\left(\Pi-S^{2}\right) A+\left(\Pi+S^{2}-2 S\right) B-2(\Pi-S) M_{1}\right]
$$

The expression in the square brackets is the difference between the weighted means of the political leader types and the preferences of the decisive voter, where the weights depend on the relative frequency of $A$ and $B$ winning assembly votes and the probability of ostracism at the second stage. Equation (7) can be rearranged as a quadratic equation with respect to $S$, namely $\Delta=(B-A)\left[(B-A) S^{2}-2\left(B-M_{1}\right)+\Pi\left(A+B-2 M_{1}\right)\right]$. The roots of the latter are $S_{1}=\frac{\Pi(4+\Pi)}{8} \frac{B-A}{B-M_{1}}$ and $S_{2}=\frac{2\left(B-M_{1}\right)}{B-A}-S_{1} \cdot{ }^{29}$ We may then write

$$
\Delta=(B-A)^{2}\left(S-S_{1}\right)\left(S-S_{2}\right)
$$

Equation (8) cannot be signed unambiguously at this level of generality owing to the complexity of the factors determining the decisive voter's choice. Table 2 provides an exhaustive list of the signs of $\Delta$ (second column) for all possible combinations of the two roots, $S_{1}$ and $S_{2}$ upon assuming $S_{1}<S_{2}$, the corresponding choices of $M_{1}$ at the first stage on whether or not to call an ostracism vote (third column), and the outcome of the second stage ostracism vote (fourth column). In sum, the choice of the decisive voter in the assembly to vote for or against ostracism depends on his perception of the types of the political leaders in comparison to his preferences and the probability that the second stage vote banishes the political leader he dislikes most.

It nevertheless is expected that factors tending to increase the $V_{1}^{O}-V^{N}$ difference are likely to lead $M_{1}$ to support holding an ostracism vote. Formally, when $\frac{d \Delta}{d z}>0, z=$ $\Pi, S, A, B, M_{1}$, it is more likely that $M_{1}$ chooses to call an ostracism vote as $z$ increases.

${ }^{29}$ In deriving the roots, the approximation $\sqrt{1+p x+q x^{2}} \approx 1+\frac{p}{2} x+\frac{1}{2}\left(q-\frac{p^{2}}{4}\right) x^{2}$ was made, where $x=\frac{1}{\left(B-M_{1}\right)}, p=\Pi(B-A)$ and $q=\Pi(B-A)\left(A-M_{1}\right)$. 
Table 2 First and second stage outcomes

\begin{tabular}{|c|c|c|c|}
\hline & $\Delta=(B-A)^{2}\left(S-S_{1}\right)\left(S-S_{2}\right)$ & $\begin{array}{l}\text { 1st stage outcome: } M_{1} \\
\text { chooses }\end{array}$ & $\begin{array}{l}\text { 2nd stage outcome: } M_{2} \\
\text { chooses }\end{array}$ \\
\hline$S_{1}<S_{2}<0$ & $\Delta>0$ for all $0 \leq S \leq 1$ & Ostracism & $\begin{array}{l}B \text { ostracised with } \\
\text { probability } \Pi^{\mathrm{a}}\end{array}$ \\
\hline \multirow[t]{2}{*}{$S_{1}<0<S_{2}<1$} & $\Delta<0$ for $0<S<S_{2}$ & No ostracism & \\
\hline & $\Delta>0$ for $S_{2}<S<1$ & Ostracism & $\begin{array}{l}B \text { ostracised with } \\
\text { probability } \Pi^{\mathrm{a}}\end{array}$ \\
\hline$S_{1}<0<1<S_{2}$ & $\Delta<0$ for all $0 \leq S \leq 1$ & No ostracism & \\
\hline \multirow[t]{3}{*}{$0<S_{1}<S_{2}<1$} & $\Delta>0$ for $0<S<S_{1}$ & Ostracism & $\begin{array}{l}B \text { ostracised with } \\
\text { probability } \Pi^{\mathrm{a}}\end{array}$ \\
\hline & $\Delta<0$ for $S_{1}<S<S_{2}$ & No ostracism & \\
\hline & $\Delta>0$ for $S_{2}<S<1$ & Ostracism & $\begin{array}{l}B \text { ostracised with } \\
\text { probability } \Pi^{\mathrm{a}}\end{array}$ \\
\hline \multirow[t]{2}{*}{$0<S_{1}<1<S_{2}$} & $\Delta>0$ for $0<S<S_{1}$ & Ostracism & $\begin{array}{l}B \text { ostracised with } \\
\text { probability } \Pi^{\mathrm{a}}\end{array}$ \\
\hline & $\Delta<0$ for $S_{1}<S<1$ & No ostracism & \\
\hline $1<S_{1}<S_{2}$ & $\Delta>0$ for all $0 \leq S \leq 1$ & Ostracism & $\begin{array}{l}B \text { ostracised with } \\
\text { probability } \Pi^{\mathrm{a}}\end{array}$ \\
\hline
\end{tabular}

${ }^{a}$ Equivalently, $A$ is ostracised with probability $1-\Pi$

This is further investigated by checking the comparative static properties of (7); the latter are shown in Table A1 of the Appendix.

We may then infer that the outrage of the Athenians regarding the 416 ostracism of Hyperbolus (although as it was described above there is considerable doubt whether the ostracism was engineered by the collusion of the other contenders) may simply reflect that the first stage decisive voter had thought that ostracism of Hyperbolus was unlikely, so ex ante he was happy to vote for ostracism, but he was unhappy ex post with the second stage outcome.

Moreover, Table A2 of the Appendix explores the voting outcomes when the parameters $S, \Pi$ and $M_{1}$ take specific values. Of special interest is the circumstance in which $M_{1}$ knows with certainty the result of the second stage in which $A$ or $B$ is ostracized (respectively $\Pi=0$, or $\Pi=1$ ). Such a scenario effectively makes $M_{1}$ the decisive voter at both the first and second stages; that may be a fair representation of the fourth century assembly. During that period two important reforms took place. First, the assembly's quorum threshold was set at 6000 , that is, equal to the quorum of the second stage of the ostracism ballot. Second, payments were made to the first 6000 citizens arriving to attend the assembly, which made it easier for poorer Athenians and those originating from rural areas to be present. As a result, it is quite possible that the first and second stage decisive voters effectively were identical. Even under this circumstance, the decisive voter may not call for ostracism, because his payoff is higher when both politicians participate actively in Athenian politics. Based on those findings, the reason ostracism fell into disuse during the fourth century may not be that the Athenians saw the ostracism of Hyperbolus as an abuse of the mechanism, but that with the expansion of attendance in the assembly, the first stage decisive voter, fully predicting the second stage result, could see no benefit from banishing any particular politician. Furthermore, when the weight attached to $A$ 's participation in politics equals the probability that $A$ is not ostracized, $S=\Pi, \Delta$ is unambiguously negative, 
implying that $M_{1}$ never will choose to support an ostracism vote because it risks banishing a political leader whose presence is valued.

In the light of this analysis, the infrequent use of ostracism may be attributed to the twostage nature of the process, wherein the decisive voter at the first stage differs from the decisive voter at the second stage. Unsure of the second stage outcome, the pivotal firststage voter is ex ante better off by deciding to keep both rival political leaders. Analytically, as soon as $M_{1}$ calls an ostracism vote he no is longer decisive, and $M_{2}$ determines $M_{1}$ 's payoff. It is rational for $M_{1}$ to call for an ostracism vote only if he is confident that $M_{2}$ will banish the politician that $M_{1}$ also wants banished. The results indicate that the alleged self-restraint of the demos in using ostracism is fully compatible with self-interest. The two-stage structure of the procedure implies that the uncertainty of the second stage vote ("who is ostracised"), represented by the probabilities $\Pi$ and $1-\Pi$, is the key to understanding why it was rare for the assembly to call for an ostracism vote in the first place. As a corollary of the unpredictability of the second round outcome, it made little, if any, sense for any politician, or his closest allies, to trigger the ostracism mechanism at the first stage in order to instigate the expulsion of a rival. A call for an ostracism vote might easily have backfired and resulted in the banishment of the instigator.

\section{Conclusions}

Research on the ancient Athenian practice of ostracism has explored the objective of the process by which political leaders were banished for a fixed, albeit long period of time from active politics, but did not incur any other material punishment. The present study considers ostracism as a negative referendum on political leaders and offers a new perspective on the process of ostracism by using concepts from the economics of conflict, game theory and spatial decision theory to examine the incentive of the constitutional writer who introduced the mechanism and the choices of the decisive voters in the twostage vote process of ostracism.

It is argued that adoption of the ostracism procedure is compatible with a conceptualization of its aristocratic author, Cleisthenes, as a rational political actor motivated by his own private interests, rather than a democratic ideology. Those interests included his quest for political supremacy and the neutralization of conflicts that threatened his political ambitions. Most probably, Cleisthenes conceived ostracism as a way to get rid of potential tyrants and political enemies on the basis of the majority's lack of support for them. However, as an early example of "the law of unintended consequences" it evolved into an inexpensive constitutional mechanism (compared to violence and civil war) for resolving other policy differences regarding defence, foreign policy and public finance issues. By demonstrating the lack of popular support for a political leader it eliminated that politician from the stage. In turn, elimination of a political actor was indicative of the policy direction preferred by the majority of citizens.

Second, the present study dwelt on the two-stage nature of the ostracism decision. It demonstrated that the decisive voter at the first stage, where the assembly took a vote on whether or not to conduct an ostracism vote, differed from the decisive voter at the second stage, where the citizenry, that is, a larger electorate, cast their ballots on expelling one political leader. Since the decisive voter at the first stage no longer was decisive at the second stage, he would vote for ostracism if he was confident that the outcome at the second stage was congruent with his own preferences. If he lacked that confidence, he was 
better off by not calling for ostracism. It is for this reason that the Athenians used the mechanism infrequently. That is, over and above possible moral arguments, the admirable restraint of the Athenians in using ostracism sparingly is explained by the model of rational choice. Furthermore, reasons exist for believing that in the fourth century BCE the decisive first stage voter was more like the decisive voter at the second stage, so that he could predict accurately the political leader who would be ostracized. However, since the benefit derived from banishing a politician always must be set against the benefit maintaining the status quo, not calling for ostracisms was perfectly consistent with expected utility maximisation of the decisive voter. All in all, one may reasonably conclude that the process of ostracism was acceptable to ordinary voters because it served as an outlet for expressing their preferences about incumbent political leaders. It also was acceptable to the elites who must have seen it as a comparatively mild form of punishment, but also costly to game.

Acknowledgments Previous versions of the paper have been presented to the Economic and Ancient History Workshop in Hildesheim, 2016, and the 2016 European Public Choice Conference in Freiburg. I wish to thank Roland Vaubel and participants in those events for the comments and suggestions on earlier versions of the paper. I am also grateful to William F. Shughart II and two anonymous referees for insightful comments and helpful suggestions on an earlier version of this paper. The usual disclaimer applies.

Open Access This article is distributed under the terms of the Creative Commons Attribution 4.0 International License (http://creativecommons.org/licenses/by/4.0/), which permits unrestricted use, distribution, and reproduction in any medium, provided you give appropriate credit to the original author(s) and the source, provide a link to the Creative Commons license, and indicate if changes were made.

\section{Appendix}

See Tables A1 and A2.

Table A1 Comparative static properties of $\Delta$

\begin{tabular}{|c|c|c|}
\hline \multicolumn{3}{|c|}{$\Delta=V_{1}^{O}-V_{1}^{N}=(B-A)\left[\left(\Pi-S^{2}\right) A+\left(\Pi+S^{2}-2 S\right) B-2(\Pi-S) M_{1}\right] ; B>A$} \\
\hline As a result of a an increase in the & $\begin{array}{c}\text { The likelihood that } M_{1} \\
\text { calls an ostracism }\end{array}$ & If \\
\hline Probability that $B$ is ostracised, $\Pi$ & Increases (decreases) & $M_{1}<(>) \frac{1}{2}(A+B)$ \\
\hline Weight of type $A$ politician in $M_{1}$ 's valuation when & Decreases & $B<M_{1}$ \\
\hline both politicians are present, $S$ & Increases (decreases) & $\begin{array}{l}B>M_{1} \text { and } \\
S>(<) \frac{B-M_{1}}{B-A}\end{array}$ \\
\hline Extremity of type $A$ politician ${ }^{\mathrm{a}}$ & Increases (decreases) & $\Pi>(<) S^{2}$ \\
\hline Extremity of type $B$ politician ${ }^{\mathrm{a}}$ & Increases (decreases) & $\Pi>(<) S(2-S)$ \\
\hline Extremity of $M_{1}{ }^{\mathrm{a}}$ & Increases (decreases) & $S>(<) \Pi$ \\
\hline
\end{tabular}

\footnotetext{
${ }^{a}$ Increase in extremity indicates a rightward shift of $x=A, B, M_{1}$
} 
Table A2 First and second stage outcomes under special cases

\begin{tabular}{lll}
$\Delta=$ & 1 st stage: & 2nd stage: \\
$M_{1}$ & $M_{2}$ chooses \\
chooses & \\
\hline
\end{tabular}

$S=1$ :

$A$ dominates politics

$$
\begin{aligned}
& (1-\Pi)(B-A)\left(2 M_{1}-(A+B)\right) \\
& >0 \text { when } M_{1}>\frac{1}{2}(A+B)
\end{aligned}
$$$$
<0 \text { when } M_{1}<\frac{1}{2}(A+B)
$$

$S=0:$

$B$ dominates politics

$$
\Pi\left(\left(M_{1}-B\right)^{2}-\left(M_{1}-A\right)^{2}\right)
$$$$
>0 \text { when } M_{1}<\frac{1}{2}(A+B)
$$

$$
<0 \text { when } M_{1}>\frac{1}{2}(A+B)
$$

$\Pi=0$ :

$M_{1}$ is certain that $M_{2}$ will ostracises $A$

$$
\begin{aligned}
& (B-A) S\left[2 M_{1}-(S A+(2-S) B)\right] \\
& >0 \text { when } M_{1}>\frac{1}{2}(S A+(2-S) B) \\
& <0 \text { when } M_{1}<\frac{1}{2}(S A+(2-S) B)
\end{aligned}
$$

$\Pi=1$ :

$M_{1}$ is certain that $M_{2}$ will ostracises $B$

$$
(B-A)(1-S)\left[(1+S) A+(1-S) B-2 M_{1}\right]
$$$$
>0 \text { when } M_{1}<\frac{1}{2}((1+S) A+(1-S) B)
$$$$
<0 \text { when } M_{1}>\frac{1}{2}((1+S) A+(1-S) B)
$$

Ostracism

No

ostracism

$B$ ostracised with probability $\Pi^{\mathrm{a}}$

No

ostracism

Ostracism

$A$ ostracised

No

ostracism

Ostracism $\quad B$ is ostracised

No

ostracism

No

ostracism

in politics = probability $A$ is not ostracised

$M_{1}=A: 1$ st stage decisive voter partisan in favour of $A$

$(B-A)^{2}\left(S^{2}-2 S+\Pi\right)$

$<0$ when $(1-S)^{2}<1-\Pi$

No

$>0$ when $(1-S)^{2}>1-\Pi$

ostracism

Ostracism $\quad B$ ostracised with

probability $\Pi^{\mathrm{a}}$

$(B-A)^{2}\left(S^{2}-\Pi\right)$

$<0$ when $S^{2}<\Pi$

No

ostracism

$>0$ when $S^{2}>\Pi$

Ostracism $\quad B$ ostracised

with

probability

$\Pi^{\mathrm{a}}$

$\begin{array}{ccc}M_{1}=1 / 2(A+B): M_{1} \text { unbiased } & -S(1-S)(B-A)^{2}<0 & \text { No } \\ \text { between } A \text { and } B & \text { ostracism }\end{array}$

$B>A$ by assumption

a Equivalently, $A$ is ostracised with probability $1-\Pi$ 


\section{References}

\section{Ancient sources}

Aristotle. The Athenian Constitution

Plutarch, Parallel Lives: Alcibiades, Aristides, Nicias, Pericles, Themistocles

\section{Modern authors}

Alvarez, R. M., \& Kiewiet, D. R. (2009). Rationality and rationalistic choice in the california recall. British Journal of Political Science, 39, 267-290.

Andrewes, A. (1992). The peace of Nicias and the Sicilian expedition. In D. M. Lewis, J. Boardman, J. K. Davies, \& M. Ostwald (Eds.), Cambridge ancient history, Vol. V, The Fifth Century B.C. (2nd ed., pp. 433-463). Cambridge: Cambridge University Press.

Becker, G. S., \& Stigler, G. S. (1974). Law enforcement, malfeasance, and compensation of enforcers. Journal of Legal Studies, 3, 1-18.

Cartledge, P. (2006). Ostracism in ancient Greece. Available at http://www.historyandpolicy.org/papers/ policy-paper-43.html.

D'Amico, D. J. (2010). The prison in economics: private and public incarceration in Ancient Greece. Public Choice, 145, 461-482.

Fleck, R. K., \& Hanssen, F. A. (2006). The origins of democracy: a model with applications to Ancient Greece. Journal of Law and Economics, 49, 115-146.

Forsdyke, S. (2000). Exile, ostracism and the Athenian democracy. Classical Antiquity, 19, 232-263.

Forsdyke, S. (2005). Exile, ostracism and democracy. The politics of expulsion in Ancient Greece. Princeton: Princeton University Press.

Garfinkel, M. R., \& Skaperdas, S. (2007). Economics of conflict: an overview. In T. Sandler \& K. Hartley (Eds.), Handbook of defense economics (pp. 649-709). New York: North-Holland.

Hammond, N. G. L. (1988). The expedition of Xerxes. In J. Boardman, N. G. L. Hammond, D. M. Lewis, \& M. Ostwald (Eds.), Cambridge ancient history, Vol. IV, Persia, Greece and the Western Mediterranean c.525 to 479 BC (2nd ed., pp. 518-592). Cambridge: Cambridge University Press.

Hansen, M. H. (1999). The Athenian democracy in the age of Demosthenes: Structure, principles and ideology. London: Bristol Classical Press.

Hillman, A. L. (2010). Expressive behavior in economics and politics. European Journal of Political Economy, 26, 404-419.

Kagan, D. (1961). The origin and purposes of ostracism. Hesperia, 30, 393-401.

Kaiser, B. A. (2007). The Athenian Trierarchy: mechanism design for the private provision of public goods. The Journal of Economic History, 67, 445-480.

Kyriazis, N. K. (2009). Financing the Athenian state: public choice in the age of demosthenes. European Journal of Law and Economics, 27, 109-127.

Leeson, P. T. (2007). An-arrgh-chy: the law and economics of pirate organization. Journal of Political Economy, 115, 1049-1094.

Leeson, P. T., \& Coyne, C. J. (2012). Conflict-inhibiting norms. In M. R. Garfinkel \& S. Skaperdas (Eds.), The oxford handbook of the economics of peace and conflict (pp. 840-860). Oxford: Oxford University Press.

Lewis, D. M. (1992). The thirty years' peace. In D. M. Lewis, J. Boardman, J. K. Davies, \& M. Ostwald (Eds.), Cambridge Ancient History, Vol. V,The Fifth Century B.C (2nd ed., pp. 121-146). Cambridge: Cambridge University Press.

Lyttkens, C. H. (2013). Economic analysis of institutional change in Ancient Greece: politics, taxation and rational behaviour. Abingdon: Routledge.

McCannon, B. C. (2010). The median juror and the trial of Socrates. European Journal of Political Economy, 26, 533-540.

Ober, J. (2008). Democracy and knowledge. Princeton: Princeton University Press.

Ober, J. (2015). The rise and fall of classical Greece. Princeton and Oxford: Princeton University Press.

Olson, M. (1965). The Logic of Collective Action, Public Goods and the Theory of Groups. Cambridge: Harvard University Press.

Ostwald, M. (1988). The reform of the Athenian state by Cleisthenes. In J. Boardman, N. G. L. Hammond, D. M. Lewis, \& M. Ostwald (Eds.), Cambridge ancient history, Vol. IV, Persia, Greece and the 
Western Mediterranean c.525 to 479 BC (2nd ed., pp. 303-346). Cambridge: Cambridge University Press.

Persson, T., \& Tabellini, G. (1999). The size and scope of government: comparative politics with rational politicians. European Economic Review, 43, 699-733.

Pitsoulis, A. (2011). The egalitarian battlefield: reflections on the origins of majority rule in archaic Greece. European Journal of Political Economy, 27, 87-103.

Rhodes, P. J. (1992). The Athenian revolution. In D. M. Lewis, J. Boardman, J. K. Davies, \& M. Ostwald (Eds.), Cambridge Ancient History, Vol. V, The Fifth Century B.C (2nd ed., pp. 62-95). Cambridge: Cambridge University Press.

Rosenbloom, D. (2004a). Ponêroi vs. Chrêstoi: the ostracism of Hyperbolos and the struggle for hegemonoi in Athens after the death of Perikles, Part I. Transactions of the American Philological Association, $134,55-105$.

Rosenbloom, D. (2004b). Ponêroi vs. Chrêstoi: the ostracism of Hyperbolos and the struggle for hegemonoi in Athens after the death of Perikles, Part II. Transactions of the American Philological Association, $134,323-358$.

Shaw, D., McKenzie, M. J., \& Underwood, J. (2005). Strategic voting in the California recall election. American Political Research, 32, 216-245.

Taylor, C. (2007). From the whole citizen body? The sociology of election and lot in the Athenian democracy. Hesperia, 76, 323-346.

Tridimas, G. (2011). A political economy perspective of direct democracy in ancient Athens. Constitutional Political Economy, 22, 58-72.

Tridimas, G. (2012). Constitutional choice in ancient Athens: the rationality of selection to office by lot. Constitutional Political Economy, 23, 1-21.

Tridimas, G. (2013). Homo oeconomicus in ancient Athens. Silver bonanza and the choice to build a navy. Homo Oeconomicus, 30, 14-162.

Tridimas, G. (2015a). War, disenfranchisement and the fall of the ancient Athenian democracy. European Journal of Political Economy, 31, 102-117.

Tridimas, G. (2015b). Rent seeking in the democracy of ancient Greece. In A. L. Hillman \& R. D. Congleton (Eds.), The Elgar companion to the political economy of rent seeking (pp. 444-469). Cheltenham: Edward Elgar Publishing. 